\title{
Intraguild predation between the aphidophagous ladybird beetles Harmonia axyridis and Coccinella undecimpunctata (Coleoptera: Coccinellidae): the role of body weight
}

\author{
SANDRA FÉLIX and ANTÓNIO ONOFRE SOARES
}

\begin{abstract}
Department of Biology, University of the Azores, Rua da Mãe de Deus, Apart. 1422, PT-9501-801 Ponta Delgada, Portugal; e-mail: onofre@notes.uac.pt
\end{abstract}

\begin{abstract}
Key words. Harmonia axyridis, Coccinella undecimpunctata, intraguild predation (IGP), asymmetrical IGP mobility, body-weight
\end{abstract}
\begin{abstract}
The magnitude, direction and symmetry of intraguild predation (IGP) between the developmental stages of the aphidophagous Harmonia axyridis Pallas and Coccinella undecimpunctata L. were characterized and compared. Mobility and body weight were the main factors affecting the magnitude of IGP.

H. axyridis was more often the predator than $C$. undecimpunctata and eggs the most vulnerable developmental stage. There was significant asymmetrical IGP on eggs by the second and later, and fourth larval stages of $H$. axyridis and C. undecimpunctata, respectively. Asymmetrical IGP of pupae was only recorded for the fourth larval stage of $H$. axyridis. There was no IGP between adults, but larvae of both species attacked heterospecifics. The best model of the relationship between rate of predation and the difference in the body weight of IG predator and prey differs for the two ladybirds. A small difference in the body weights leads to a marked increase in the rate of predation in H. axyridis but not in C. undecimpunctata. In asymmetrical combinations, increase in body weight of the intraguild predator did not significantly increase the rate of predation. Mobility and body weight were not the only important parameters involved in the symmetry of IGP. Aggressive behaviour of $H$. axyridis negatively affected the survival of C. undecimpunctata.
\end{abstract}

\section{INTRODUCTION}

Intraguild predation (IGP) is the killing and consumption of a species that uses similar resources and therefore a potential competitor. It is a common and often important interaction. In a diverse array of communities, IGP occurs among members of the same guild (Polis \& Holt, 1992). The aggressor is the intraguild predator (IG predator), the victim the intraguild prey (IG prey), and the common resource is the extraguild prey (Lucas et al., 1998). IGP is considered to be an extreme form of competition or a type of classical predation that may affect the distribution, abundance and evolution of animal species. IGP not only provides an additional food resource for IG predators, but may reduce inter- or intraspecific competition and predation risk for the extraguild prey when mutual IGP occurs (Polis et al., 1989; Polis \& Holt, 1992; Lucas et al., 1998; Yasuda et al., 2001). IG prey populations may suffer local extinctions due to IGP, which is an important mortality factor (Lucas et al., 1998; Dixon, 2000).

The two most important factors that determine the symmetry and direction of IGP are the size and degree of feeding specificity exhibited by the protagonists. IGP occurs mainly when generalist predators attack prey of smaller size, including conspecifics (Polis et al., 1989; Polis \& Holt, 1992; Lucas et al., 1998). The size of the prey generally increases with the size/age of the IG predator (Sabelis, 1992), with smaller individuals being more vulnerable to large predators (Werner \& Gilliam, 1984; Lucas et al., 1998). In ladybird beetles, large species usually eat small species, which could result in asym- metrical interactions between two species (Obrycki et al., 1998). A specialized predator should be less adapted to attack a nonpreferred prey, a disadvantage when confronted with a generalist predator (Lucas et al., 1998).

The mobility of the protagonists also determines the direction of IGP as fleeing is a common and effective defence strategy (Edmunds, 1974; Sih, 1987; Lucas et al., 1998). The sessile stages are vulnerable since they are more easily captured (New, 1991; Lucas et al., 1998). Eggs are particularly vulnerable because they are laid close to aphids and so not too far from places visited by larvae and adults (Hemptinne \& Dixon, 1991).

Coccinella undecimpunctata L. is a native aphidophagous predator of the Azores where it can be found mostly by the sea (salt lands) on plants where it may feed also on flower pollen. Harmonia axyridis Pallas is a paleartic species and native of Asia (Iablokoff-Khnzorian, 1982), and has not yet been introduced into the Azores. It is a very polymorphic ladybeetle in which some of the phenotypes differ in fitness (Soares et al., 2001, 2003). This euryphagous predator prefers aphids (Hukusima \& Kamei, 1970; Iablokoff-Khnzorian, 1982; Osawa, 1992), but can feed on psyllids (Fye, 1981; Drea \& Gordon, 1990), coccids (McLure, 1987; Hodek \& Honěk, 1996), immature stages and eggs of Lepidoptera (Schanderl et al., 1988; Drea \& Gordon, 1990) and spider mites (Drea \& Gordon, 1990; Lucas et al., 1997a). Laboratory tests have shown that it is a powerful biological agent for use against many phytophagous species. That this ladybird beetle can be successfully reared on the eggs of Ephestia kuehniella Zeller (Schanderl et al., 1988) makes it easy to 
produce in large number for inundative releases. However, its negative impact on native ladybird beetles and other non-target arthropods is rarely studied (c.f. Lucas et al., 2002).

There are several studies on IGP between the immature stages of $H$. axyridis and other ladybird beetles (Takahashi, 1989; Lucas et al., 1997b; Yasuda \& Shinya, 1997; Yasuda \& Ohnuma, 1999; Kajita et al., 2000; Michaud, 2002), but there are few on the direction and strength of IGP between all the developmental stages of $H$. axyridis and other predator species. The aims of this study were to characterize (i) the magnitude (ii) the direction and (iii) the symmetry of IGP between $H$. axyridis and $C$. undecimpunctata, (iv) evaluate the importance of body weight in determining the direction and strength of IGP and (v) assess the potential impact of the introduction of the exotic $H$. axyridis on the abundance of the native $C$. undecimpunctata. Because $H$. axyridis is a highly voracious euryphagous predator and is bigger than $C$. undecimpunctata, we predict that the former species will be the aggressor (IG predator) and C. undecimpunctata the victim (IG prey) in most of the interactions between their developmental stages, as previously shown by Lucas et al. (1998). We also predict that as the difference in larval body weight increases, rate of predation by the $H$. $a x y$ ridis should rapidly increase to an asymptotic maximum rate of predation.

\section{MATERIAL AND METHODS}

H. axyridis and C. undecimpunctata individuals came from a stock culture were reared at $22 \pm 1{ }^{\circ} \mathrm{C}, 75 \pm 5 \% \mathrm{RH}$ and a photoperiod of $16 \mathrm{~L}: 8 \mathrm{D}$, using fluorescent lamps (Philips ref.: TDL $23 \mathrm{~W} / 54$ and TDL $18 \mathrm{~W} / 54$ ). To avoid consanguinity and food adaptation, ladybeetles were fed ad libitum on a mixed diet (Rana et al., 2002) of the aphids Aphis fabae Scopoli and Myzus persicae (Sulzer) and eggs of Ephestia kuehniella Zeller, and field collected ladybeetles were added regularly to the stock culture.

Magnitude, direction and symmetry of IGP between all developmental stages (eggs, 4 larval stages, pupae and adults) of $H$. axyridis and $C$. undecimpunctata were characterized and compared. As there are no interactions between eggs and pupae, there are a total of 45 combinations. Larvae and adults used in the experiments were $24 \mathrm{~h}$ old. Prior to the beginning of the tests, second to fourth instars and adults were starved for $24 \mathrm{~h}$ and then weighed using a Mettler AM 50 analytical balance with a precision of $10^{-4} \mathrm{mg}$. First instars larvae were not starved but were weighed before an experiment. After weighing, an individual of one species of ladybird was placed with one of the other species in a $2 \mathrm{~L}$ transparent plastic box that contained a potted broad bean plant (approximately $15 \mathrm{~cm}$ tall) but no aphids. Five eggs were provided in the combinations that included eggs. Immobile stages (eggs and pupae) were placed on plant leaves, and mobile stages (larvae and adults) at the base of the plant. The second individual was released after the first moved up the stem. Twenty-four hours later, the box was checked to determine which individual had survived. There were 15 replicates of each combination.

The natural mortality of each instar of the two species was used as a control. A single individual of each instar was kept for $24 \mathrm{~h}$ in a $2 \mathrm{~L}$ transparent plastic box with a broad bean plant without aphids. There were 3 replicates for each combination, which gave a total of 21 replicates of each mobile stage and 15 for the two sessile stages of both $H$. axyridis and $C$. undecimpunctata.

All trials were performed at $20 \pm 1{ }^{\circ} \mathrm{C}, 75 \pm 5 \%$ of $\mathrm{RH}$ and a photoperiod of 16L : 8D, under fluorescent lamps (Philips ref.: TDL $23 \mathrm{~W} / 54$ and TDL $18 \mathrm{~W} / 54$ ).

IGP levels were estimated from the rates of predation for $H$. axyridis (RPha) and C. undecimpunctata (RPcu), which were calculated as follows:

\section{$\mathrm{RPha}=[\mathrm{P}(\mathrm{cu}, \mathrm{ha}) \mathrm{SRcu} / \mathrm{N}] 100$}

$\mathrm{RPcu}=[\mathrm{P}(\mathrm{ha}, \mathrm{cu}) \mathrm{SRha} / \mathrm{N}] 100$

where "P(cu,ha)" = number of individuals of $C$. undecimpunctata killed, "P(ha,cu)" number of individuals of $H$. axyridis killed, "SRcu" survival rate of C. undecimpunctata in control, "SRha" survival rate of $H$. axyridis in control and "N" number of replicates. Survival rates were calculated from the replicates in which single individuals were placed on plants for $24 \mathrm{~h}$, the controls.

The symmetry index of Lucas et al. (1998) was used. This index expresses the number of replicates in which a given predator was eaten over the total numbers of replicates in which there was IGP, for each particular combination of predators.

\section{Statistical analysis}

The symmetry indices for each combination were compared with the theoretical index of $50 \%$ corresponding to a symmetrical interaction, using a Chi-square test $\left(\chi^{2}, \mathrm{P}<0.05\right)$ (SPSS Production Facility, 2002). The strength of the IGP between the two species for a given combination was assessed using the $\chi^{2}$ and was considered (i) symmetrical, when the $\chi^{2}$ value was not significant, which indicated that the rate of predation of the two species was similar, (ii) asymmetrical, when the $\chi^{2}$ value was significant and (iii) not significant asymmetrical, when the $\chi^{2}$ value was not significant but the rate of predation of the two species differed.

For each combination, the average body weights of $H$. axyridis and $C$. undecimpunctata were compared using a t-test (JMP IN ${ }^{\circledR}$ 3.2.6 for PC, statistics made by SAS Institute Inc., 1989). One-factor ANOVA was used to compare larval predation rates both when $H$. axyridis and $C$. undecimpunctata was the IG predator (SPSS Production Facility, 2002).

Gompertz and exponential functions were used to evaluate the effect of body weight on the rate of predation of the larval stages of both predators. Both functions were fitted to both data sets and the best fit chosen. When $H$. axyridis was the IG predator, the best fit to the relationship between rate of predation and the difference in the body weights of predator and prey was the Gompertz function (Laterra \& Bazzalo, 1999):

$$
\mathrm{y}=\mathrm{A}+\mathrm{C}\{\exp [-\exp (-\mathrm{B}(\mathrm{x}-\mathrm{M}))]\}+\varepsilon
$$

where " $y$ " is the rate of predation, " $x$ " is the difference in body weight between the larval stages of the two ladybirds, the value "A + C" is the asymptote of the model, "B" is the slope of the curve, "M" indicates the difference in body weight at the inflection point, and " $\varepsilon$ " is the error associated with this fitting model. When C. undecimpunctata was the IG predator, the best fit was the exponential function (Zar, 1984):

$$
\mathrm{y}=\mathrm{D} \exp ^{\mathrm{Ex}}+\varepsilon
$$

where " $D$ " and "E" are the parameters of the exponential function and " $\varepsilon$ " is the error associated with this fitting model. Both models were fitted using SPSS 1.5 non-linear estimation module. 

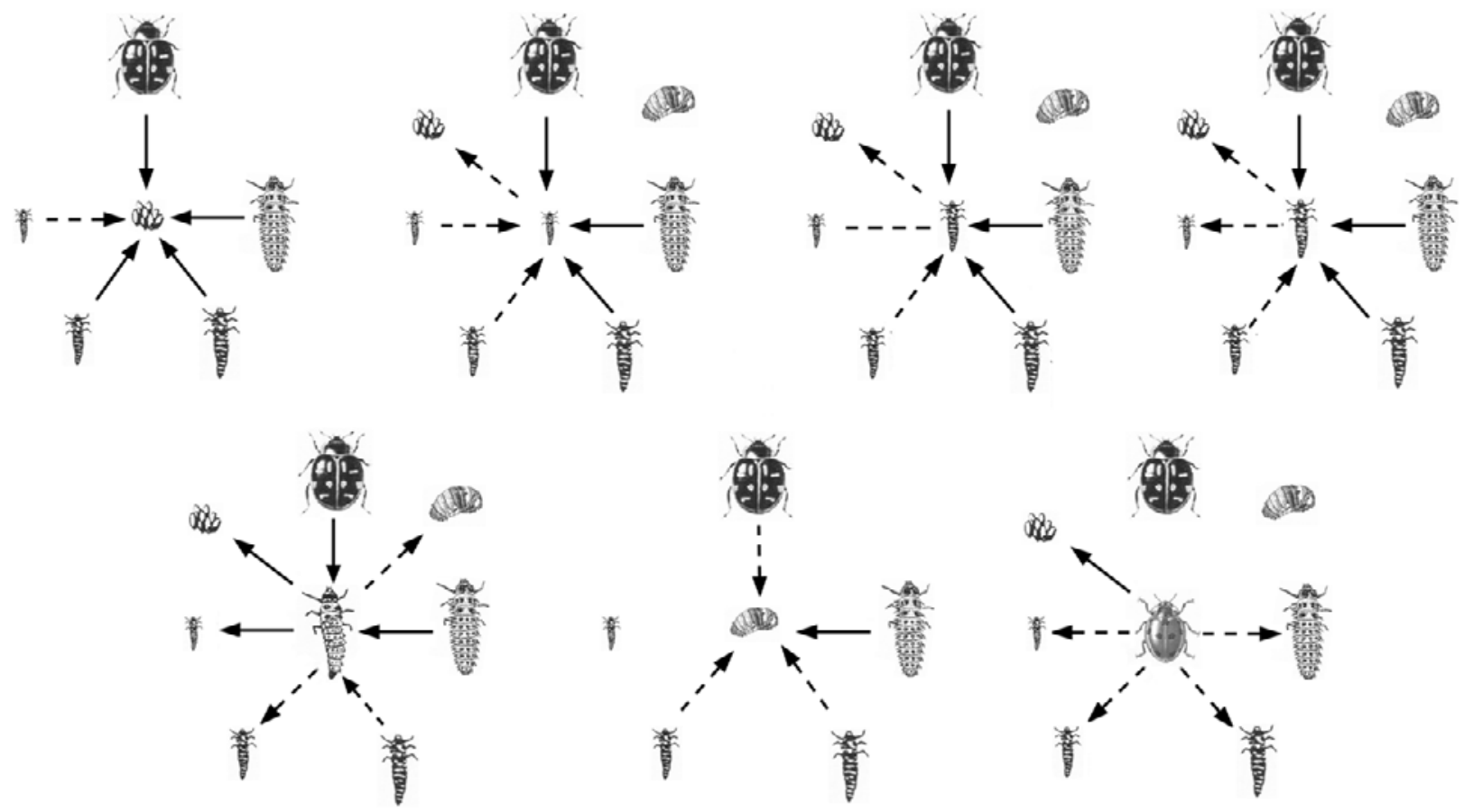

Fig. 1. Representation of the intraguild predation (IGP) between various developmental stages of $H$. axyridis and C. undecimpunctata. Complete arrow - significant asymmetrical IGP; dashed arrow - no significant asymmetrical IGP; dashed line - symmetrical IGP; lack of arrows and lines - absence of IGP; C. undecimpunctata: in central position. (Some illustrations were taken from Majerus \& Kearns, 1989.)

\section{RESULTS}

In the significant asymmetrical combinations, $H$. axyridis was the IG predator 16 and $C$. undecimpunctata only 3 times. IGP was not significantly asymmetrical in 19 and symmetrical in one combination. In combinations that were significantly asymmetrical, the rate of predation ranged between 66 and $100 \%$. The lowest rate $(66 \%)$ occurred in the combination fourth larval stage of $H$. axyridis and pupae of $C$. undecimpunctata. In combinations that were not significantly asymmetrical, the rate of predation of IG predator ranged between 7 and $70 \%$. The highest values of IGP occurred in combinations in which the IG prey was also occasionally the IG predator, such as when the first larval stage of $C$. undecimpunctata also fed on the second larval stage of $H$. axyridis (Fig. 1).

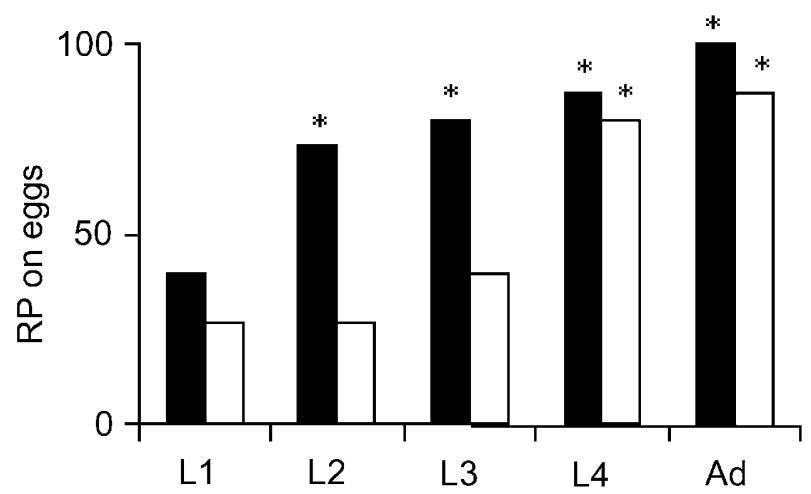

Fig. 2. Rate of predation (RP) of the immature stages and adults of $H$. axyridis (closed bars) and $C$. undecimpunctata (open bars) on eggs. * indicates significant asymmetrical IGP $\left(\chi^{2}, \mathrm{df}=1, \mathrm{P}<0.05\right)$.
Absence of IGP was observed 6 times, that is, no individuals fed on heterospecifics (Fig. 1).

Eggs were the most vulnerable developmental stage. Significant asymmetrical IGP on eggs occurred when they were combined with second, third and fourth larval stages and adults of $H$. axyridis, and fourth larval stages and adults of C. undecimpunctata (Fig. 2).

Larvae of both species attacked heterospecifics. In general, the rate of predation of the immature stages of $H$. axyridis was higher than that of the immature stages of $C$. undecimpunctata. Significant differences in rates of predation among instars were observed both when $H$. axyridis (ANOVA, $\mathrm{F}=100.69$, $\mathrm{df}=4, \mathrm{P}<0.0001$ ) and $C$. undecimpunctata was the IG predator (ANOVA, F = $75.1, \mathrm{df}=2, \mathrm{P}<0.0001)$. The relationship obtained between the rate of predation and the difference in body weight of the IG predator and prey when $H$. axyridis was the IG predator differed from when C. undecimpunctata was the IG predator. For $H$. axyridis a small difference in body weight relative to that of its prey results in a rapid increase in rate of predation (Fig. 3A). This is less true for C. undecimpunctata (Fig. 3B). At a difference in body weight of $1.74 \mathrm{mg} H$. axyridis has a high rate of predation $(86 \%)$, and at greater differences there was no further increase (Fig. 3A). However a high rate of predation (86\%) was observed for C. undecimpunctata only when the difference in weight was $4 \mathrm{mg}$ (Fig. 3B).

$H$. axyridis adults weigh more than eggs and larvae of C. undecimpunctata and IGP between these ladybirds was always significantly asymmetrical. On the other hand, despite the significantly greater body weight of adult $C$. undecimpunctata compared to the eggs and larvae of $H$. 

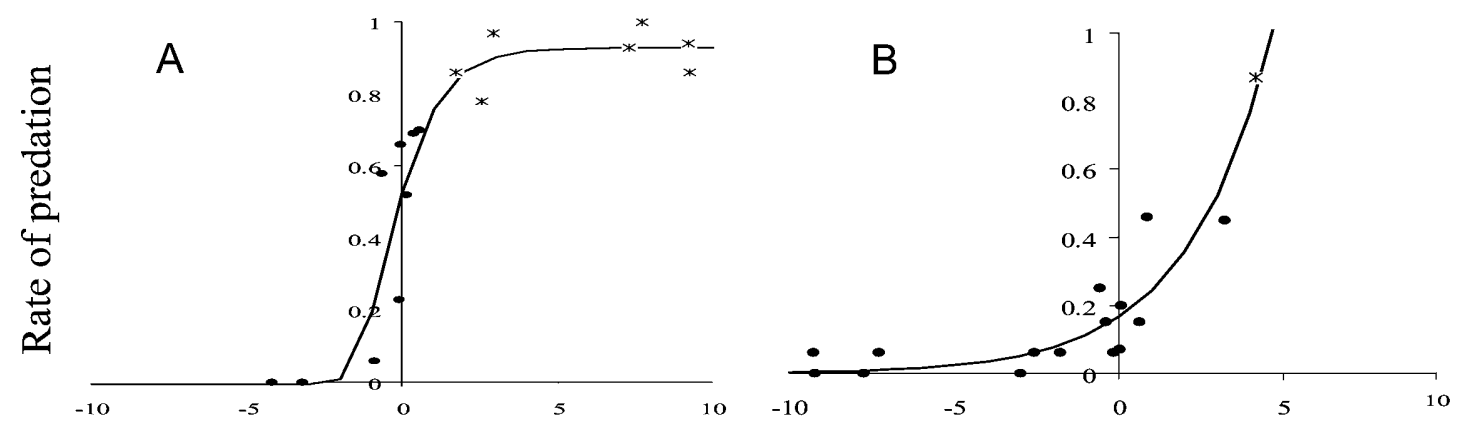

\section{Difference in body-weight $(\Delta \mathrm{BW})$ in $\mathrm{mg}$}

Fig. 3. Relation between the difference in body-weight (difference in body weight was the average weight of the IG predator minus the average weight of the IG prey, for each of the combinations) and the rate of predation of the larval stages [* indicate combinations where significant asymmetry was found $\left.\left(\chi^{2}, \mathrm{df}=1, \mathrm{P}<0.05\right)\right]$. (A) Gompertz function fitted to the results obtained, when H. axyridis was the IG predator $\left(\mathrm{Y}=-0.04+0.933\{\exp [-\exp (-1.017(\mathrm{x}-0.574))]\} \mathrm{R}^{2}=0.88\right)$; and $(\mathrm{B})$ exponential function when $C$. undecimpunctata was the IG predator $\left(\mathrm{y}=0.1657 \exp ^{0.3828 x} \mathrm{R}^{2}=0.86\right)$.

axyridis, significantly asymmetrical IGP only occurred when adults fed on eggs. IGP between adults did not occur (Table 1).

Significantly asymmetrical IGP of fourth stage larvae of $H$. axyridis on pupae of $C$. undecimpunctata occurred. In this case, the difference in body-weight between the pupae of C. undecimpunctata $(11.47 \mathrm{mg})$ and fourth larval stage of $H$. axyridis $(10.78 \mathrm{mg}$ ) was approximately $0.7 \mathrm{mg}$ (Table 2).

\section{DISCUSSION AND CONCLUSION}

We characterized the direction and strength of IGP between all the developmental stages of $H$. axyridis and C. undecimpunctata under controlled conditions. There were differences in the direction and strength of IGP between these species. As predicted, in most combinations, $H$. axyridis was the IG predator.

Due to their immobility and relatively soft integument, eggs were the most vulnerable developmental stage.

TABLE 1. Characterization of the symmetry of intraguild predation (IGP) and comparative body-weight ( $\Delta \mathrm{BW})$ of adults of $H$. axyridis and C. undecimpunctata relative to the other species developmental stages.

\begin{tabular}{|c|c|c|c|c|c|c|c|c|c|}
\hline \multicolumn{5}{|c|}{ Adult of $H$. axyridis } & \multicolumn{5}{|c|}{ Adult of C. undecimpunctata } \\
\hline C. undecimpunctata & IGP & $\Delta \mathrm{BW}^{*}$ & $\mathrm{t}^{* *}$ & $\mathrm{p}^{* *}$ & H. axyridis & IGP & $\Delta \mathrm{BW}^{*}$ & $\mathrm{t}^{* *}$ & $\mathrm{p}^{* *}$ \\
\hline Egg & $\mathrm{S}$ & 25.4 & 17.4 & $<0.0001$ & Egg & $\mathrm{S}$ & 9.1 & 10.7 & $<0.0001$ \\
\hline L1 & $\mathrm{S}$ & 28.0 & 14.7 & $<0.0001$ & L1 & NS & 10.1 & 20.4 & $<0.0001$ \\
\hline $\mathrm{L} 2$ & S & 28.2 & 31.8 & $<0.0001$ & $\mathrm{~L} 2$ & NS & 9.4 & 15.1 & $<0.0001$ \\
\hline L3 & $\mathrm{S}$ & 33.8 & 19.5 & $<0.0001$ & L3 & NS & 5.9 & 10.5 & $<0.0001$ \\
\hline L4 & S & 27.0 & 19.9 & $<0.0001$ & $\mathrm{~L} 4$ & NS & 1.5 & 2.1 & 0.04 \\
\hline Ad & $\mathrm{N}$ & 14.3 & 11.1 & $<0.0001$ & Ad & - & - & - & - \\
\hline
\end{tabular}

$\mathrm{S}$ - significantly asymmetrical; NS - no significantly asymmetrical; N - no IGP. *Body-weight differences of adults of $H$. axyridis and $C$. undecimpunctata relative to that of the other species developmental stages ( $\mathrm{t}$ test $\mathrm{p}<0.05)$. ${ }^{*} \mathrm{t}$ and $\mathrm{p}$ values for body-weight difference (t-test).

TABLE 2. Characterization of the symmetry of intraguild predation (IGP) and comparative body-weight ( $\Delta \mathrm{BW}$ ) of the pupae of $H$. axyridis and C. undecimpunctata relative to the other species larvae and adults developmental stages.

\begin{tabular}{|c|c|c|c|c|c|c|c|c|c|}
\hline \multicolumn{5}{|c|}{ Pupae of $H$. axyridis } & \multicolumn{5}{|c|}{ Pupae of C. undecimpunctata } \\
\hline C. undecimpunctata & IGP & $\Delta \mathrm{BW}^{*}$ & $\mathrm{t}^{* *}$ & $\mathrm{p}^{* *}$ & H.axyridis & IGP & $\Delta \mathrm{BW}^{*}$ & $\mathrm{t}^{* *}$ & $\mathrm{p}^{* *}$ \\
\hline L1 & $\mathrm{N}$ & -26.0 & -19.3 & $<0.0001$ & L1 & $\mathrm{N}$ & -11.2 & -19.7 & $<0.0001$ \\
\hline L2 & $\mathrm{N}$ & -36.3 & -34.8 & $<0.0001$ & L2 & NS & -9.6 & -22.6 & $<0.0001$ \\
\hline L3 & $\mathrm{N}$ & -31.4 & -24.0 & $<0.0001$ & L3 & NS & -8.6 & -14.5 & $<0.0001$ \\
\hline L4 & NS & -29.0 & -17.8 & $<0.0001$ & L4 & S & -0.7 & -0.8 & 0.45 \\
\hline Ad & $\mathrm{N}$ & -12.0 & -2.0 & 0.06 & Ad & NS & 14.3 & 11.1 & $<0.0001$ \\
\hline
\end{tabular}

$\mathrm{S}$ - significantly asymmetrical; NS - no significantly asymmetrical; N - no IGP. *Body-weight differences of pupae of $H$. axyridis and C. undecimpunctata relative to that of the other species developmental stages $(\mathrm{t}$ test $\mathrm{p}<0.05)$. **t and $\mathrm{p}$ values for body-weight difference (t-test). 
Indeed several studies identify mobility as an important defensive strategy of prey (Edmunds, 1974; Sih, 1987; New, 1991; Lucas et al., 1998). However, the immobility of pupae was not necessarily disadvantageous as $H$. axyridis pupae were almost invulnerable to IGP. When irritated pupae of $H$. axyridis show sudden movements and raise their body which along with their large size may account for their low vulnerability. C. undecimpunctata pupae rarely showed alarm responses, which is to disadvantage of this species. Other studies refer to the importance of body size in IGP, with the size of the prey generally increasing with the size of the predator (Werner \& Gilliam, 1984; Polis et al., 1989; Agarwala \& Dixon, 1992; Polis \& Holt, 1992; Sabelis, 1992; Lucas et al., 1997b, 1998; Obrycki et al., 1998). Size, strength of the integument and distastefulness, make the pupal stage less vulnerable. Thus the immobility is not the only factor affecting vulnerability.

Between larvae, the difference of the body weight of IG predator and prey determined the direction and rate of predation, in which large individuals generally killed small ones. The functions that best describe the relationships between the differences in body weight and rate of predation when $H$. axyridis and $C$. undecimpunctata are the IG predators differ, with significantly asymmetrical predation occurring when differences in body weight were $1.74 \mathrm{mg}$ and $4 \mathrm{mg}$, respectively. When there was little difference in body weight between the IG predator and prey, $H$. axyridis showed a higher rate of predation than C. undecimpunctata. Young larvae, which are small and slow, were the most likely to be IG prey (see also Agarwala \& Dixon, 1992). The more aggressive behaviour of $H$. axyridis larvae might contribute to the differences, as shown previously by Yasuda \& Ohnuma (1999), who studied IGP between $H$. axyridis and Coccinella septempunctata $\mathrm{L}$.

In all combinations of adults with larval stages and eggs, the adults were usually the predator despite the insignificant asymmetrical IGP of C. undecimpunctata on larval stages. The food specificity of predators is also an important factor influencing the outcome of IG interactions (Lucas et al., 1998; Obrycki et al., 1998; Yasuda et al., 2001). This favours $H$. axyridis, as this species is a highly euryphagous predator.

A number of studies reveal that invading species, including $H$. axyridis, have a negative impact on native ladybird beetle assemblages. $H$. axyridis becomes dominant after its invasion or introduction to control pest insects. H. axyridis replaced C. septempunctata in Midwestern USA (Horn, 1996), caused significant changes in the structure of native coccinelids communities in alfalfa, corn and small grain fields in North America (Evans, 1991; Elliott et al., 1996) and became dominant and replaced $C$. septempunctata in northern Japan after the aphids became scarce (Yasuda \& Shinya, 1997; Yasuda \& Ohnuma, 1999). Competitive displacement of Cycloneda sanguinea (L.) was reported in the citrus ecosystem of Florida (Michaud, 2002). Cannibalism, competition and IGP due to the aggressive behaviour of larvae possibly account for these replacements (Yasuda \& Ohnuma, 1999). Although there is no IGP between adults, they may interact negatively by interfering with one another when selecting oviposition sites (Lucas et al., 2002) and competing for food, etc. The significantly asymmetrical IGP of the oldest larvae of $H$. axyridis on the immature stages of $C$. undecimpunctata suggest that the introduction of the former may have a negative impact on the native populations of $C$. undecimpunctata in the Azores.

ACKNOWLEDGEMENTS. We thank H. Figueiredo and R. Resendes for technical assistance and L. Silva for his help with the statistical analysis. Thanks are also due to J. Medeiros for his help with Fig. 1 and to anonymous reviewers for their helpful comments. This research was funded by the University of the Azores, Department of Biology and Centro de Investigação dos Recursos Naturais (CIRN).

\section{REFERENCES}

Agarwala B.K. \& Dixon A.F.G. 1992: Laboratory study of cannibalism and interspecific predation in ladybirds. Ecol. Entomol. 17: 303-309.

Dixon A.F.G. 2000: Insect Predator-Prey Dynamics, Ladybird Beetles and Biological Control. Cambridge University Press, Cambridge, UK, $257 \mathrm{pp}$.

Drea J.J. \& GoRdon R.D. 1990: Coccinellidae. In Rosen D. (ed.): Armored Scale Insects-Their Biology, Natural Enemies and Control. Vol. 4B. Elsevier, New York, Amsterdam, pp. $19-40$.

Edmunds M. 1974: Defence in Animals. Longman, New York, $358 \mathrm{pp}$.

Elliott N., Kieckhefer R. \& Kauffman W. 1996: Effects of an invading coccinellid on native coccinellids in an agricultural landscape. Oecologia 105: 537-544.

Evans E.W. 1991: Intra versus interspecific interactions of ladybeetles (Coleoptera: Coccinellidae) attacking aphids. Oecologia 87: 401-408.

FYE R.E. 1981: Rearing and release of coccinellids for potential control of pear psylla. Agr. Res. Serv. (West. Reg.) 20: 1-9.

Hemptinne J.-L. \& Dixon A.F.G. 1991: Why ladybirds have generally been so ineffective in biological control? In Polgár L., Chambers R.J., Dixon A.F.G. \& Hodek I. (eds): Behaviour and Impact of Aphidophaga. SPB Acad. Publ., The Hague, pp. 149-157.

Hodek I. \& HonĚK A. 1996: Ecology of Coccinellidae. Kluwer, Dordrecht, $464 \mathrm{pp}$.

Horn D.J. 1996: Impact of introduced Coccinellidae on native species in nontarget ecosystems. (Abstract.) Symposium of the IOBC working group "Ecology of Aphidophaga". University of Agriculture, Gembloux (unpaginated).

Hukusima S. \& Kamei M. 1970: Effects of various species of aphids as food on development, fecundity, and longevity of Harmonia axyridis Pallas (Coleoptera: Coccinellidae). Res. Bull. Fac. Agric. Gifu Univ. 29: 53-66.

IABloKoff-Khnzorian S.M. 1982: Les Coccinelles; Coléoptères - Coccinellidae. Société Nouvelle des Éditions Boubée, Paris, $568 \mathrm{pp}$.

Kajtta Y., Takano F., Yasuda H. \& Agarwala B.K. 2000: Effects of indigenous ladybird species (Coleoptera: Coccinellidae) on the survival of an exotic species in relation to prey abundance. Appl. Entomol. Zool. 35: 473-470.

Laterra P. \& Bazzalo M.E. 1999: Seed-to-seed allelopathic effects between two invaders of burned pampa grasslands. Weed Res. 39: 297-308. 
Lucas E., Coderre D. \& Vincent C. 1997a: Voracity and feeding preferences of two aphidophagous coccinellids on Aphis citricola and Tetranychus urticae. Entomol. Exp. Appl. 85: $151-159$.

Lucas E., Coderre D. \& Brodeur J. 1997b: Instar-specific defense of Coleomegilla maculata lengi (Col.: Coccinellidae): Influence on attack success of the intraguild predator Chrysoperla rufilabris (Neur.: Chrysopidae). Entomophaga 42: $3-12$

LuCAS E., Coderre D. \& Brodeur J. 1998: Intraguild predation among aphid predators: characterization and influence of extraguild prey density. Ecology 79: 1084-1092.

Lucas E., Gagné I. \& Coderre D. 2002: Impact of the Harmonia axyridis on adults of Coccinella septempunctata and Coleomegilla maculata (Coleoptera: Coccinellidae). Eur. J. Entomol. 99: 457-463.

Majerus M. \& Kearns P. 1989: Ladybirds. The Richmond Publishing, Slough, 103 pp.

McLuRE M.S. 1987: Potential of the Asian predator, Harmonia axyridis Pallas (Coleoptera: Coccinellidae), to control Matsucoccus resinosae Bean \& Godwin (Homoptera: Margarodidae) in the United States. Environ. Entomol. 16: 224-230.

Michaud J.P. 2002: Invasion of the Florida citrus ecosystem by Harmonia axyridis (Coleoptera: Coccinellidae) and asymmetric competition with a native species, Cycloneda sanguinea. Environ. Entomol. 31: 827-835.

New T.R. 1991: Insects as Predators. New South Wales University Press, Kensington, 178 pp.

Obrycki J.J., Giles K.L. \&. ORMord A.M. 1998: Interactions between an introduced and indigenous coccinellid species at different prey densities. Oecologia 117: 279-285.

Osawa N. 1992: A life table of the ladybird beetle Harmonia axyridis Pallas (Coleoptera: Coccinellidae) in relation to the aphid abundance. Jpn. J. Entomol. 60: 575-579.

Polis G.A. \& Holt R.D. 1992: Intraguild predation: The dynamics of complex trophic interactions. Trends Ecol. Evol. 7: $151-154$.

Polis G.A., Myers C.A. \& Holt R.D. 1989: The ecology and evolution of intraguild predation: potential competitors that eat each other. Annu. Rev. Ecol. Syst. 20: 297-330.
Rana J.S., Dixon A.F.G. \& Jarošík V. 2002: Costs and benefits of prey specialization in a generalist insect predator. J. Anim. Ecol. 71: 15-22.

Sabelis M.W. 1992: Predatory arthropods. In Crawley M.J. (ed.): Natural Enemies. Blackwell, Oxford, pp. 225-264.

Schanderl H., Ferran A. \& Garcia V. 1988: L'élevage de deux coccinelles Harmonia axyridis et Semiadalia undecimnotata à l'aide d'oeufs d'Anagasta kuehniella tués aux rayons ultraviolets. Entomol. Exp. Appl. 49: 417-421.

Siн A. 1987: Predators and prey lifestyles: an evolutionary and ecological overview. In Kerfoot C.W. \& Sih A. (eds): Predation: Direct and Indirect Impacts on Aquatic Communities. University Press of New England, Hanover, New Hampshire, pp. 203-224.

SoAres A.O., Coderre D. \& Schanderl H. 2001: Influence of phenotype on fitness parameters of Harmonia axyridis Pallas (Coleoptera: Coccinellidae). Eur. J. Entomol. 98: 287-293.

Soares A.O., Coderre D. \& Schanderl H. 2003: Effect of temperature and intraspecific allometry on predation by two phenotypes of Harmonia axyridis Pallas (Coleoptera: Coccinellidae). Environ. Entomol. 32: 939-944.

SPSS 2002: SPSS Base 11.5 for Windows Users Guide. Chicago, USA.

TAKAHASHI K. 1989: Intra- and interspecific predations of lady beetles in spring alfalfa fields. Jpn. J. Entomol. 57: 199-203.

Werner E.E. \& Gilliam J.F. 1984: The ontogenetic niche and species interactions in size-structured populations. Annu. Rev. Ecol. Syst. 15: 393-425.

Yasuda H. \& Shinya K. 1997: Cannibalism and interspecific predation in two predatory ladybirds in relation to prey abundance in the field. Entomophaga 42: 153-163.

YASUda H. \& OHNuma N. 1999: Effect of cannibalism and predation on the larval performance of two ladybird beetles. Entomol. Exp. Appl. 93: 63-67.

Yasuda H., Kikuchi T., Kindlmann P. \& Sato S. 2001: Relations between attack and escape rates, cannibalism, and intraguild predation in larvae of two predatory ladybirds. J. Insect Behav. 14: 373-384.

ZAR J.H. 1984: Biostatistical Analysis. 2nd ed. Prentice-Hall, New Jersey, 718 pp. 